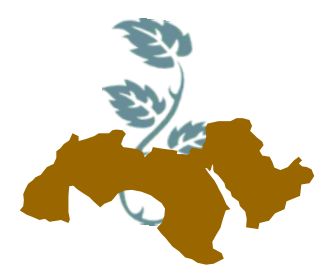

\author{
1053 \\ Arab Univ. \\ J. Agric. Sci., \\ Ain Shams Univ., Cairo \\ Special Issue, 26(2A), 1053-1064, 2018
}

\title{
COMPUTATIONAL MODEL TO IMPROVE DAIRY ANIMAL FEEDING UNDER MIXED FARMING SYSTEM (CROPS/LIVESTOCK) AS STUDY CASE
}

\author{
Ismail $^{1}$ H.M.; A.F. Al-Sadek ${ }^{2}$; A.A. Ashmawy ${ }^{3}$; M.A.I. KhaliI ${ }^{1}$ \\ and Manal Elsayed ${ }^{3}$ \\ 1- Animal Production Research Institute, Agric. Research Center, Ministry of Agric., Dokki, Giza, \\ Egypt \\ 2- The Central Laboratory for Agric. Expert Systems (CLAES), Agric. Research Center, Ministry \\ of Agric., Dokki, Giza, Egypt \\ 3- Animal Production Dept., Fac. of Agric., Ain Shams Univ., Cairo, Egypt
}

Keywords: Mixed farming system, dairy animal feeding and computation models

\section{ABSTRACT}

Computational model was designed for feeding systems of small dairy farms in Egypt under Mixed Farming System (MFS) (Crops/livestock). The present case study was selected from El-Beheira governorate, where the three common dairy animals (Local cows, Crossbred cows and buffaloes) are available. The main objectives of this study were 1To find out the optimum combination of inputs from farm green forage and cash crops to minimize animal feeding costs. 2- Asses the possibilities of increasing the farm income by least cost rations formulation using available feed resources for dairy cattle. Technical coefficients of the models were obtained from previous studies under Egyptian condition. The model proposed three scenarios: Scenario I (S I) calculated the actual feeding situation from the case study without any changes as base run, scenario II (S II) proposed to cover animal feeding requirements of the same herd in scenario (S I) from the same available feed resources according to NRC (2001) and scenario III (S III) operating on the available feeding package quantities or reallocated farm feed resources for the same herd. The model used the common feed in summer and winter seasons (300 days) while, two months were considered as transitional period between two seasons, where irregular animal feeding regime is adopted. The results showed that area cultivated with green forages can be reduced by
$17 \%$ and $25 \%$ of total planted area in SII for winter and summer, respectively, compared to base run (SI). Where as in S III, the green forage cultivated areas reduced by $30 \%$ and $25 \%$ for winter and summer, respectively in comparison with $\mathrm{SI}$, feeding costs in SIl were reduced by $51.11 \%$ and $38.97 \%$ in winter and summer, respectively. Using available feeding packages and reallocated farm resources in SIII reduced feeding costs by $47.78 \%$ and $27.67 \%$ for winter and summer, respectively. It can be concluded that using available feeding packages or reallocated animal feeding resources either in SII and SIII achieved a considerable reduction on animal feeding costs of small-scale mixed farms compared to base run scenario (SI).

\section{INTRODUCTION}

In recent times, there has been a proliferation of whole-farm models (WFMs) to address a multitude of questions in agricultural systems (Janssen and van Ittersum's 2007). Thornton and Herrero (2001) reported that mixed crop-livestock systems provide over $50 \%$ of the world's meat and over $90 \%$ of its milk and compromise the most common form of livestock operation in developing countries. In addition, mixed systems include $70 \%$ of the poor livestock keepers. An obvious interaction between livestock and land is through the management of stocking rates, which plays a large part in defining the productivity of farm systems. Farmers' continuously aims frequently to apply the best mixed farming activities that maximize their farm income. In other words, they look for the best possible ways 
of distributing their limited resources for cropping and livestock activities and often follow their traditions and practices in this regard. Such practice does not always guarantee optimal results. In Egypt, Berseem (trifolium alexandrinum) is the main winter forage crop that almost fed at adlibitum as a common practice. Feeding berseem with its low calorie / protein ratio generally covers $96 \%$ of energy and $177 \%$ of protein requirements of animals' population (Youssef, 1978). Darawa or sorghum is the main summer fodder crops in delta of Egypt, rich in calorie\% and poor in protein\%. New technique to formulate rations in winter and summer was suggested to formulate balanced rations from available farm resources to cover animal requirements in both seasons. Modeling technique plays a significant role in assessing the impact of innovation feeding packages or reallocates the farm resources objectively to increase the farm income before execution on a large scale. Models have the advantage of testing any intervention in farming systems precisely and quickly. They make use of the physical input/output of the data in the form in which they are commonly available. This technique offers a powerful tool in analyzing prevailing production systems and simulation of the behavior of complex systems. Khalil et al (2005), Khalil et al (2010) and El-Giziry et al (2011) used modeling techniques to improve crop/livestock production system in the Nile Delta Region of Egypt.

\section{MATERIALS AND METHODS}

Computer model was designed to generate different scenarios based on multiple parameters of the livestock and the crops in the farm. The model equations have to achieve farm objectives functions that reduce feeding cost and maximize farm income from livestock and cash crops. The model contains several components as shown in (Fig. 1).

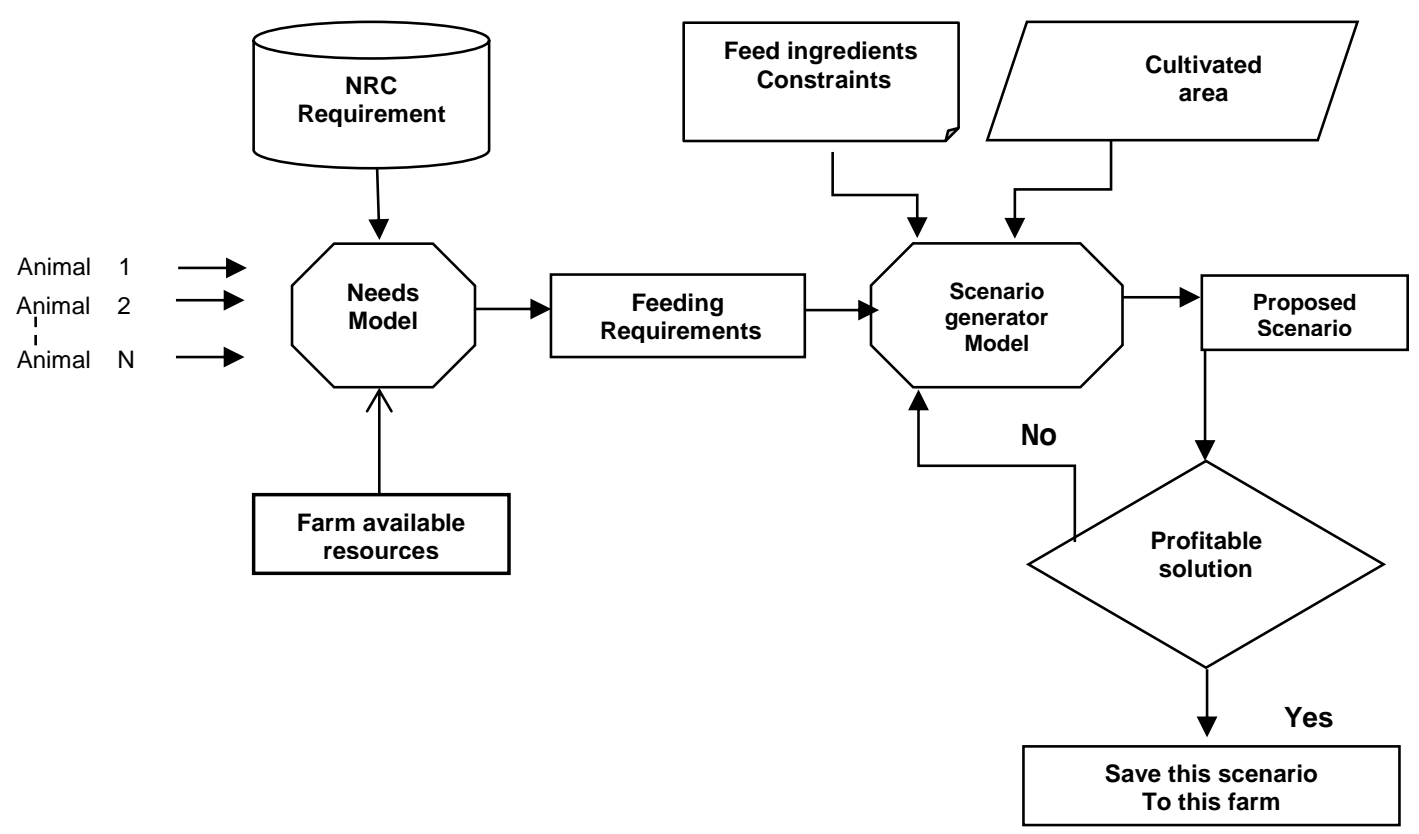

Fig. 1. Schematic of computational model plan for dairy animal feeding performance NRC: National Research Council-USA. 

system (crops/livestock) as study case

Technical and economical coefficients of the model were obtained from animal nutrition and agricultural experts and pre-tested on many farms data and modifications were conducted then to adjust calculations and results were revised by animal production experts. One farm was selected that has three common dairy animals (Local cows, Crossbred cows sand buffaloes) with average body weight $350 \mathrm{~kg}, 450 \mathrm{~kg}$ and $550 \mathrm{~kg}$ respective$\mathrm{ly}$, to validate the model operation.

At first, the user will record the productivity of each animal in the farm of interest. Then the model will calculate the feeding requirements (FR) for recorded animals based on NRC (2001), the output of this step will be represented as dry matter (DM), crude protein (CP) and total digested nutrients (TDN) quantity per day for the three animals of this farm. Each animal has its own nutritive requirements according to milk production and body weight.

Second step, the model utilize the farm feeding requirements trying to generate proposed scenario taking into account the cultivated area and some constraints for each component of available ingredients. The constraints in the model were: green forage range from $20 \%$ to $70 \%$, straw range from $10 \%$ to $20 \%$ and concentrate range from $0 \%$ to $20 \%$ of animal FR. The percentage of each component in three previous rations was determined depending on previous studies that were done by (Khalil et al 2005; Khalil et al 2010 and El-Giziry et al 2011) within mixed farming systems under conditions of Egyptian small dairy farms.

\section{The functions of the used model were}

Animals feed $=\sum_{i=1}^{3} X i=100$

$20 \leq \mathrm{X}_{1} \leq 70$

$10 \leq X_{2} \leq 20$

$0 \leq X_{3} \leq 20$

Where: $X_{1}$ is green forage, $X_{2}$ is wheat straw and $X_{3}$ is a concentrate.

Also, the model considered that cultivated area could be cultivated twice per year and produces cash crops and green forage. Part of this crop is used for home consumption and the rest for sale. The by-products of cash crops and green forage cultivated area are used mainly for animal feeding and the surplus can be sold or used for other purposes. Finally, the system will be checked if the proposed scenario is more profitable than the cur- rent situation for the same farm or not. In case, it is not then, the system will repeat the steps of generating a different scenario till reach the maximum profit for this farm with the same resources. The lower costs rations can cover animal FR from available green forages plus minimum purchased concentrate feeds will be saved for this farm case. Feeding costs and revenues for cash crops and milk sales at farm level was calculated to estimate the gross margin.

Two scenarios were proposed for the case study to enhance farm income better than its current base run one. Scenario I (S I) used the actual inputs from field data without any change as base run scenario. Scenario II (S II) proposed improved and balanced rations to cover animal FR for the same dairy animals with the same available farm feeds resources with lower cost according to NRC (2001). Scenario III (S III) used balanced animal $\mathrm{FR}$ of the previous herd with using available feed resources with conserved surplus green forage as corn silage and/or berseem hay. In both proposed scenarios, extra $10 \%$ of rations were added over calculated FR as safety margin. The present study will be continued with more farms in the same area to validate the model. The farms will be selected as mixed farming system (crops and livestock) five dairy cows or less with cultivated land five feddans or less.

Winter feeding season is starting from mid of November to mid of April then followed by one month as transitional period till mid of May. Summer feeding season is starting from mid of May till mid of October followed by one month as second transitional period. Two transitional periods between two seasons were not considered because animals have irregular feeding regime. Annex 1 . Green forages used in animal feeding in ElBeheira according to Economic Affairs sectors (2014). Annex 2 concentrate feed, straws and conserved green forage used in animal feeding in the studied area.

\section{RESULTS AND DISCUSSION}

Feeding system of the dairy animals in winter and summer seasons depends mainly on the green forage production in most of the Egyptian mixed farms. In winter, berseem is cultivated in relatively large areas. While in summer farmer cultivated Sorghum or Darawa in fresh feeding and conserve some of production for winter feeding. Farmer also used supplementary feeds either as 
commercial concentrates or homemade mixtures (wheat bran, corn, cotton seed cake or any available farm grains).Wheat straws were commonly used all over the year. The common animal feeding pattern that offered to animals is presented in Table (1) as base rune scenario (S I).

Corn silage was added to dairy rations more than other feed ingredients (straw and concentrate) because it is really two feedstuffs: highmoisture corn grain with high energy contents and grass silage as forage. Berseem was used as green forage in winter and corn silage was used as green forage in summer in addition to CFM and wheat straw in both seasons. Usually, berseem is mixed with agricultural by-products or grasses in the first cut in order to adjust moisture content to avoid troubles such as digestive disorders caused by feeding animals on Berseem alone (Abou-Slim and Bendary 2005).

Table (2) shows feed quantities (FR) that given to the animal after transformed into feeding values as DM, CP and TDN. Animal feed balance between dairy animal requirements according to NRC (2001) and actual animal feeding in winter and summer were recorded. The results showed that DM and CP intake for all dairy animals in winter were higher than the recommended requirements while, TDN intake was lower.

Table 1. The common animal feeding pattern in winter and summer as base run scenario (SI)

\begin{tabular}{|l|c|c|c|c|c|}
\hline & $\begin{array}{c}\text { Anim } \\
\text { No. }\end{array}$ & $\begin{array}{c}\text { Berseem* } \\
\text { kg/day/anim. }\end{array}$ & $\begin{array}{c}\text { Conc. Mix. } \\
\text { Kg/day/anim. }\end{array}$ & $\begin{array}{c}\text { Wheat straw } \\
\text { Kg/day/anim. }\end{array}$ & $\begin{array}{c}\text { Corn silage } \\
\text { Kg/day/anim. }\end{array}$ \\
\hline \multicolumn{7}{|c|}{ Winter feeding } \\
\hline Crossbred cow & 2 & 65 & 2.0 & 6.0 & - \\
Local cow & 1 & 50 & 1.0 & 4.0 & - \\
Buffaloes & 2 & 75 & 2.0 & 7.0 & - \\
\hline Total /day & $\mathbf{5}$ & $\mathbf{3 3 0}$ & $\mathbf{9}$ & $\mathbf{3 0}$ & - \\
\hline \multicolumn{7}{|c|}{ Summer feeding } \\
\hline Crossbred cow & 2 & - & 3.0 & 8.0 & 20 \\
Local cow & 1 & - & 2.0 & 6.0 & 15 \\
Buffaloes & 2 & - & 3.5 & 9.0 & 25 \\
\hline Total /day & $\mathbf{5}$ & - & $\mathbf{1 5}$ & $\mathbf{4 0}$ & $\mathbf{1 0 5}$ \\
\hline
\end{tabular}

*Berseem 1 kirat with average $330 \mathrm{~kg} /$ day/ all owned animals.

Table 2. Daily animal feeding requirements for three breeds compared with current winter and summer feeding pattern

\begin{tabular}{|c|c|c|c|c|c|}
\hline $\begin{array}{l}\text { Milking } \\
\text { animals }\end{array}$ & $\begin{array}{c}\text { No. of } \\
\text { Animal. }\end{array}$ & $\begin{array}{c}\text { Av. Milk } \\
\text { Prod./day/ } \\
\text { animal (kg) }\end{array}$ & $\begin{array}{l}\text { Dry Matter } \\
\text { (DM) } \\
\text { (kg)/animal }\end{array}$ & $\begin{array}{c}\text { Total Digestible } \\
\text { Nutrients (TDN) \% } \\
\text { /animal }\end{array}$ & $\begin{array}{c}\text { Crude } \\
\text { Protein } \\
\text { (\%)/animal }\end{array}$ \\
\hline \multicolumn{6}{|c|}{ Animal requirement based on NRC } \\
\hline Cross breed & 2 & 10 & 11.00 & 61.00 & 12.08 \\
\hline Local cow & 1 & 5 & 7.80 & 59.25 & 10.03 \\
\hline Buffalo & 2 & 7 & 12.50 & 61.50 & 12.50 \\
\hline \multicolumn{6}{|c|}{ Winter animal feeding pattern } \\
\hline Cross breed & 2 & 10 & 17.73 & 57.02 & 13.25 \\
\hline Local cow & 1 & 5 & 12.6 & 57.14 & 13.49 \\
\hline Buffalo & 2 & 7 & 20.25 & 56.87 & 13.17 \\
\hline \multicolumn{6}{|c|}{ The Differences } \\
\hline Cross breed & 2 & 10 & 6.73 & -3.98 & 1.17 \\
\hline Local cow & 1 & 5 & 4.80 & -2.11 & 3.46 \\
\hline Buffalo & 2 & 7 & 7.75 & -4.06 & 0.70 \\
\hline \multicolumn{6}{|c|}{ Summer animal feeding pattern } \\
\hline Cross breed & 2 & 10 & 16.90 & 60.07 & 7.69 \\
\hline Local cow & 1 & 5 & 12.45 & 59.86 & 7.53 \\
\hline Buffalo & 2 & 7 & 20.0 & 60.66 & 7.76 \\
\hline \multicolumn{6}{|c|}{ The Differences } \\
\hline Cross breed & 2 & 10 & 5.90 & -0.93 & -4.39 \\
\hline Local cow & 1 & 5 & 4.65 & 0.61 & -2.50 \\
\hline Buffalo & 2 & 7 & 7.50 & -0.84 & -4.74 \\
\hline
\end{tabular}



system (crops/livestock) as study case

Also, during summer DM fed to dairy animals was higher than requirement, while $\mathrm{CP}$ intake was lower and TDN was very close to the animals FR. The results showed that offered DM was generally higher in winter and summer seasons. Extra CP was offered to animals in winter while, in summer there was shortage. These results could be explained by the abundant supply of berseem (high in CP content) in winter season and limited supply of protein in summer forage (poor in CP).

The imbalances of FR during both seasons (winter and summer) may have negative impact on productive and reproductive performance of dairy animals (El-Ashmawy, et al 2003 and El-Wardani et al 2005). The results of common dairy animals feeding showed that berseem plays an important role in winter feeding. Adding corn silage adding can reduce berseem quantity with effective adjustment of the unbalanced berseem ration.
However, replacement a part of berseem by corn silage during winter feeding and a part of corn silage by berseem hay in summer feeding may overcome the dietary imbalance. This assumption was used as a base in building the two other improved scenarios (S II and S III) for dairy animals.

Tables (3 and 4) show the proposed scenario SII for winter and summer compared with traditional feeding in base run scenario (S I). Farmer used corn silage only in summer season with high quantities for dairy animals plus CFM as source of protein and wheat straw. The proposed scenario SII was calculated to cover animal FR according to NRC (2001). The proposed scenario substituted part of berseem in winter feeding by corn silage while, quantities of corn silage in summer were adjusted. Furthermore, part of excess berseem in winter was conserved for summer feeding as berseem hay.

Table 3. Scenrio II (S II) animal feeding systems in winter and summer

\begin{tabular}{|l|c|c|c|c|c|}
\hline & $\begin{array}{c}\text { Anim } \\
\text { No. }\end{array}$ & $\begin{array}{c}\text { Berseem } \\
\text { Kg/day/anim. }\end{array}$ & $\begin{array}{c}\text { Conc. Mix. } \\
\text { Kg/day/anim. }\end{array}$ & $\begin{array}{c}\text { Wheat straw } \\
\text { Kg/day/anim }\end{array}$ & $\begin{array}{c}\text { Corn silage } \\
\text { Kg/day/anim. }\end{array}$ \\
\hline Winter feeding & & & & & \\
\hline Cross breed & 2 & 40.0 & 0.0 & 2.5 & 8.0 \\
Local cow & 1 & 20.0 & 0.0 & 4.0 & 7.0 \\
Buffalo & 2 & 42.0 & 0.0 & 2.0 & 10.0 \\
\hline Total winter feed & $\mathbf{5}$ & $\mathbf{1 8 4}$ & $\mathbf{0}$ & $\mathbf{1 3}$ & $\mathbf{4 3}$ \\
\hline Summer feeding & & Berseem hay & & & Corn silage \\
\hline Cross breed & 2 & 2.0 & 5.0 & 0.0 & 13.0 \\
Local cow & 1 & 4.0 & 2.0 & 6.0 & 7.0 \\
Buffalo & 2 & 6.0 & 4.0 & 3.0 & 2.0 \\
\hline Total Summer feed & $\mathbf{5}$ & $\mathbf{2 0}$ & $\mathbf{2 0}$ & $\mathbf{1 2}$ & $\mathbf{3 7}$ \\
\hline
\end{tabular}

The rations were formulated according to NRC (2001)

Table 4. Comparing feeds quantities between two Scenarios (SI) and (S II) in winter and summer.

\begin{tabular}{|l|c|c|c|c|c|}
\hline & $\begin{array}{c}\text { Anim } \\
\text { No. }\end{array}$ & $\begin{array}{c}\text { Berseem } \\
\text { Kg/day/anim. }\end{array}$ & $\begin{array}{c}\text { Conc. Mix. } \\
\text { Kg/day/anim. }\end{array}$ & $\begin{array}{c}\text { Wheat straw } \\
\text { Kg/day/anim }\end{array}$ & $\begin{array}{c}\text { Corn silage } \\
\text { Kg/day/anim. }\end{array}$ \\
\hline Winter feeding & & & & & \\
\hline Cross breed & 2 & $25(38 \%)$ & $2(100 \%)$ & $3.5(58 \%)$ & $-8(100 \%)$ \\
Local cow & 1 & $30(60 \%)$ & $1(100 \%)$ & $0(0 \%)$ & $-7(100 \%)$ \\
Buffalo & 2 & $33(44 \%)$ & $2(100 \%)$ & $5(71 \%)$ & $-10(100 \%)$ \\
\hline Total winter feed & $\mathbf{5}$ & $\mathbf{1 4 6}$ & $\mathbf{9}$ & $\mathbf{1 7}$ & $-\mathbf{4 3}$ \\
\hline Summer feeding & & Berseem hay & & & Corn silage \\
\hline Cross breed & 2 & $-2(100 \%)$ & $-2(67 \%)$ & $8(100 \%)$ & $7(35 \%)$ \\
Local cow & 1 & $-4(100 \%)$ & $0(0 \%)$ & $0(0 \%)$ & $8(53 \%)$ \\
Buffalo & 2 & $-6(100 \%)$ & $-0.5(14 \%)$ & $6(67 \%)$ & $23(92 \%)$ \\
\hline Total Summer feed & $\mathbf{5}$ & $\mathbf{- 2 0}$ & $\mathbf{- 5}$ & $\mathbf{2 8}$ & $\mathbf{6 8}$ \\
\hline
\end{tabular}


The proposed scenario would be more suitable for farmers who own less cultivated areas for animal feeding with either less available or expensive CFM in market. Using corn silage in S II in winter feeding shall contribute to reduce berseem quantities for all animals compared with the same animals in SI. Whereas, straw was reduced for crossbreed and buffalo in winter and summer seasons. Wheat straw was higher in base run scenario than FR while, in scenario SIl with adjusted buffalo and crossbred animals FR decreased. Comparing two proposed (SII) with (SI) for cultivated area, it was found that 23 kirats of berseem are required for animal feeding in winter in addition to 3 tons berseem hay for summer feeding (produced from seven kirats in the third and fourth cuts). While, the first and second cuts production will be for sale.

The quantity of wheat straw saved in winter was 2.55 tons in addition to 4.2 tons in summer; the total saved quantity is 6.75 tons. The requirement for all animals of corn silage is $6450 \mathrm{~kg}$ in winter and $5550 \mathrm{~kg}$ in summer, $12000 \mathrm{~kg}$ in total that means by computational model calculation, we can save $5250 \mathrm{~kg}$ it equivalent 0.25 feddan (6 kirats). The present case study showed the misused of farm available feed resources. It means that feeding cost will be higher than recommended animal FR. Also, the feeding systems did not cover all nutritive values for the animals according to their production and physiological statues. Powell et al (2016) reported that the whole farm simulations illustrated that growing more corn silage and less alfalfa reduces the land requirement for feed production by approximately $27 \%$, maintains milk production, increases animal $\mathrm{N}$ use efficiency (from 20 to $25 \%$ ), and decreases manure $\mathrm{N}$ excretion (from 26.5 to $20.8 \mathrm{~g} \mathrm{~N} / \mathrm{kg}$ milk). These findings revealed that partial replacement of corn silage can reduce berseem quantity with effectively adjusting the unbalanced berseem content in ration (i.e. given berseem as a sole component of ration for dairy animals).

Pervious results are agreed with the findings reported by Khalil et al (2010) who found that feeding corn silage by $6 \mathrm{~kg} / \mathrm{animal} /$ day for fattening Friesian claves reduced CFM from $30.76 \%$ to $14.00 \%$ and as much as corn silage increased in the ration to $12 \mathrm{~kg} / \mathrm{animal} / \mathrm{day}$ the CFM reduced to $8.00 \%$ in the ration.

Regarding SII in summer feeding, CFM increased for crossbred and buffalo by $67 \%$ and
$14 \%$, respectively while for local cow was the same consumption. The same animals needed $750 \mathrm{~kg}$ CFM more than farmer fed in summer while, in winter farmer feed $1350 \mathrm{~kg}$ more than animals FR. It means that $600 \mathrm{~kg}$ in total are saved for the five dairy animals in winter and summer.

Although, berseem plays an important role in winter feeding, but the addition of corn silage and berseem hay in proper quantities with other feed ingredients can achieve efficient use of ration with improving digestion coefficients in general. In addition, CFM as the most expensive item in the ration (in total quantity in winter and summer) can be reduced so that feeding cost will be consequently decline.

Tables (5 and 6) show other proposed model (S III) for the same farm with the same animals for winter and summer seasons. The same objective in SII was considered in the proposed SIII to cover animal FR with less feeding costs. In this scenario the dietary ground corn was included in winter as source of energy instead of corn silage. The adjustment of corn silage quantity to cover animal FR. Green berseem fed in S III was reduced daily for crossbred cows, local and buffalos compared with SI. While, CFM fed to the animals was reduced only for crossbred and local animals. Wheat straw was decreased for all animals. The same scenario in summer feeding by adding berseem hay and adjust the corn silage quantities in ration, the CFM was increased for crossbred and buffalo. Whereas, other ration components (straw and corn silage) were reduced.

Twenty five kirats were required for animal feeding in SIII divided into 20 kirats for winter feeding plus 5 kirats from $3^{\text {rd }}$ and $4^{\text {th }}$ cuts for summer feeding as berseem hay (2.4 tons). Concerning that CFM $450 \mathrm{~kg}$ are saved in winter, while in summer $900 \mathrm{~kg}$ more CFM is required. It means that in total $450 \mathrm{~kg}$ CFM are needed more for the farm in both seasons. Wheat straw was saved by $2460 \mathrm{~kg}$ and $4050 \mathrm{~kg}$ in winter and summer, respectively, the total saved quantity was $6510 \mathrm{~kg}$. The requirement of ground corn was $1950 \mathrm{~kg}$ in winter while, corn silage was $4050 \mathrm{~kg}$ in summer, so 0.25 feddan ( 6 kirats) can be saved. From scenarios II and III it can be concluded that rations in summer and winter should be justified to reduce feeding costs in order to save lands that are cultivated with green forage and animals can have their FR. 
Table 5. Scenario III (SIII) animal feeding systems in winter and summer

\begin{tabular}{|l|c|c|c|c|c|}
\hline & $\begin{array}{c}\text { Anim } \\
\text { No. }\end{array}$ & $\begin{array}{c}\text { Berseem } \\
\text { Kg/day/anim. }\end{array}$ & $\begin{array}{c}\text { Conc. Mix. } \\
\text { Kg/day/anim. }\end{array}$ & $\begin{array}{c}\text { Wheat straw } \\
\text { Kg/day/anim. }\end{array}$ & $\begin{array}{c}\text { Ground corn } \\
\text { Kg/day/anim. }\end{array}$ \\
\hline Winter feeding & & & & & \\
\hline Cross breed & 2 & 30.0 & 1.0 & 2.5 & 3.0 \\
Local cow & 1 & 20.0 & 0.0 & 2.6 & 3.0 \\
Buffalo & 2 & 40.0 & 2.0 & 3.0 & 2.0 \\
\hline Total winter feed & $\mathbf{5}$ & $\mathbf{1 6 0}$ & $\mathbf{6}$ & $\mathbf{1 3 . 6}$ & $\mathbf{1 3}$ \\
\hline Summer feeding & & Berseem hay & & & Corn silage \\
\hline Cross breed & 2 & 1.0 & 5.5 & 2.0 & 9.0 \\
Local cow & 1 & 2.0 & 2.0 & 3.0 & 5.0 \\
Buffalo & 2 & 6.0 & 4.0 & 3.0 & 2.0 \\
\hline Total summer feed & $\mathbf{5}$ & $\mathbf{1 6}$ & $\mathbf{2 1}$ & $\mathbf{1 3}$ & $\mathbf{2 7}$ \\
\hline
\end{tabular}

Table 6. Differences in feeds quantities between two Scenarios (SI) and (S III) in winter and summer

\begin{tabular}{|l|c|c|c|c|c|}
\hline & $\begin{array}{c}\text { Anim } \\
\text { No. }\end{array}$ & $\begin{array}{c}\text { Berseem } \\
\text { Kg/day/anim. }\end{array}$ & $\begin{array}{c}\text { Conc. Mix. } \\
\text { Kg/day/anim. }\end{array}$ & $\begin{array}{c}\text { Wheat straw } \\
\text { Kg/day/anim. }\end{array}$ & $\begin{array}{c}\text { Ground corn } \\
\text { Kg/day/anim. }\end{array}$ \\
\hline Winter feeding & & & & & \\
\hline Cross breed & 2 & $35(54 \%)$ & $1(50 \%)$ & $3.5(58 \%)$ & $-3(100 \%)$ \\
Local cow & 1 & $30(60 \%)$ & $1(100 \%)$ & $1.4(35 \%)$ & $-3(100 \%)$ \\
Buffalo & 2 & $35(47 \%)$ & $0(0 \%)$ & $4(57 \%)$ & $-2(100 \%)$ \\
\hline Total winter feed & $\mathbf{5}$ & $\mathbf{1 7 0}$ & $\mathbf{3}$ & $\mathbf{1 6 . 4}$ & $-\mathbf{1 3}$ \\
\hline Summer feeding & & Berseem hay & & & Corn silage \\
\hline Cross breed & 2 & $-1(100 \%)$ & $-2.5(83 \%)$ & $6(75 \%)$ & $11(45 \%)$ \\
Local cow & 1 & $-2(100 \%)$ & $0(0 \%)$ & $3(50 \%)$ & $10(33 \%)$ \\
Buffalo & 2 & $-6(100 \%)$ & $-0.5(14 \%)$ & $6(67 \%)$ & $23(8 \%)$ \\
\hline Total Summer feed & $\mathbf{5}$ & $\mathbf{- 1 6}$ & $\mathbf{- 6}$ & $\mathbf{2 7}$ & $\mathbf{7 8}$ \\
\hline
\end{tabular}

Schils et al (2007) found that the adjustment accounted for 37 to $84 \%$, and the mean differences between modeled and observed values varied between -5 to $+3 \%$ per set of farms. Ghanem et al (2005) showed that replacement $50 \%$ fresh berseem (25 kg/head/day) by rice straw silage reduced the feed cost of lactating cows by $19.91 \%$ without any adverse effects on milk production and its composition. Khalil et al (2010) reported that the feeding cost saving with fixed level of daily gain for proposed scenario 2 (using corn silage with 6 $\mathrm{kg} / \mathrm{day}$ ) for fattening calves and scenario 3 (double the corn silage in ration) for fattening calves, the simulation costs were saved by L.E.2.50 (23.8\%) and L.E.3.10 (29.5\%)/head/day, respectively compared to base run scenario (S1).

The optimal cropping patterns output for proposed scenarios to increase farm income from crops and livestock are shown in Table (7). The cropping pattern obtained from $\mathrm{S} I$ as base run represented the actual crop rotation in case study of small scale mixed farming systems. In the $1^{\text {st }}$ scenario (S I), farmer used to feed green forages incorrectly specially in winter where a big quantity of berseem was offered with wheat straw. In summer also corn silage as green forage are also misused, in addition to the losses, the rations in most cases were unbalanced and costly. Therefore, crop pattern in S II as model results for the same animals and cultivated area with some constraints have to cover FR in winter and summer. While, SIII used the available land with the same cropping patterns and corn silage making to save a part of berseem as hay in the studied farm in correct way to fulfill the dairy animals requirements and reducing costs of feeding.

In winter, the green forages cultivated area decreased from 36 kirats to 30 and 25 kirats with saving areas by $(17 \%)$ and $(30 \%)$ in SII and SIII, respectively. While, wheat cultivated areas in- 
creased by 6 and 11 kirats (7\%) and (14\%). In summer, reductions in green forage were 6 kirats (25\%) for both S II and S III compared to base run (S I). Rice cultivated areas increased by $6(18 \%)$ for both S II and S III. Cash crops cultivated areas were increased (wheat or rice) and green forage areas decreased in S II and S III, thus farm income would be maximized.

Table 7. The proposed scenarios of cropping pattern in different seasons in the studied farm

\begin{tabular}{|c|c|c|c|}
\hline Area in Kerat & $\begin{array}{c}\text { Scenario } \\
\text { (I) } \\
\text { Base Run }\end{array}$ & $\begin{array}{c}\text { Scenario } \\
\text { (II) } \\
\text { Balanced } \\
\text { Ration }\end{array}$ & $\begin{array}{c}\text { Scenario } \\
\text { (III) } \\
\text { Balanced } \\
\text { Ration }\end{array}$ \\
\hline \multicolumn{4}{|c|}{ Winter crops } \\
\hline Berseem ${ }^{*}$ & 36 & 30 & 25 \\
\hline Wheat & 81 & 87 & 92 \\
\hline Sugar beet & 24 & 24 & 24 \\
\hline \begin{tabular}{|ll} 
Total & planted \\
area & \\
\end{tabular} & 141 & 141 & 141 \\
\hline \multicolumn{4}{|c|}{ Summer crops } \\
\hline Corn"* & 24 & 18 & 18 \\
\hline Rice & 33 & 39 & 39 \\
\hline Water melon & 48 & 48 & 48 \\
\hline \begin{tabular}{|ll} 
Total & planted \\
area & \\
\end{tabular} & 105 & 105 & 105 \\
\hline
\end{tabular}

Feddan=24 Kirat, Kirat $=175 \mathrm{~m}^{2}$.

*one and half feddans of berseem cultivated for animal feeding and one feddan for sale

**One feddan corn cultivated for animal feeding as silage and two and half feddan for sale

Economic efficiency for the proposed two feeding scenarios are shown in Table (8). It was indicated that the total feeding costs for five animals/ day was L.E. 163.4 in SI while partial replacement of berseem by corn silage or adding berseem hay in summer in scenarios (SII and SIII) reduced the daily feed costs by LE 74.8 and 63.5/ five dairy animals/day, respectively, without any adverse effects on milk production. The corresponding reduction values as a percentage were 45.11 and $37.80 \%$, respectively on average for winter and summer. El-Giziry et al (2011) reported that daily feed cost decreased with involving rice straw silage and corn stalk silage in the rations of ruminant animals by 14.44 and $6.95 \%$, respectively. Moreover, the same authors found that revenues from buffalos feeding these rations increased by 7.64 and $10.84 \%$ compared with control ration.
Table 8. Economic efficiency for lactating animals over feeding costs

\begin{tabular}{|l|c|c|c|}
\hline \multicolumn{1}{|c|}{ Economic efficiency } & $\begin{array}{c}\text { (S I) } \\
\text { Base } \\
\text { Run }\end{array}$ & $\begin{array}{c}\text { (S II) } \\
\text { Balanced } \\
\text { Ration }\end{array}$ & $\begin{array}{c}\text { (S III) } \\
\text { Balanced } \\
\text { Ration }\end{array}$ \\
\hline $\begin{array}{l}\text { Total milk revenues } \\
\text { (LE./day) }\end{array}$ & 170 & 170 & 170 \\
$\begin{array}{l}\text { Total Feed costs } \\
\text { (LE./day)/ winter }\end{array}$ & 180.2 & 88.1 & 94.1 \\
$\begin{array}{l}\text { Total Feed costs } \\
\text { (LE./day)/summer }\end{array}$ & 146.0 & 89.1 & 105.6 \\
$\begin{array}{l}\text { Av. Feed costs (LE./day) } \\
\text { Milk revenues - Feed } \\
\text { costs (LE./day) }\end{array}$ & 163.4 & 88.6 & 99.9 \\
$\begin{array}{l}\text { Feed costs/1 kg milk } \\
\text { (LE./day) }\end{array}$ & 0.96 & 0.52 & 0.59 \\
$\begin{array}{l}\text { Input/output ratios } \\
\text { Return/Egyptian pound }\end{array}$ & $\begin{array}{l}1.04 \\
0.04\end{array}$ & $\begin{array}{l}1.92 \\
0.92\end{array}$ & 1.70 \\
0.70
\end{tabular}

The proposed scenarios used a fixed number of animals, fixed cultivated area with a fixed level of production. The improvement in the efficiency of the proposed scenarios was measured as feed cost per $1 \mathrm{~kg}$ milk, output / input ratio, and return / Egyptian pound. The obtained results from the proposed scenarios showed that milk revenue minus feeding cost of animals can be improved from LE 6.6 in the actual situation (scenario I) to LE 81.4 and LE 70.1 as suggested from the SII and SIII in the studied farms, respectively. Reduction of feeding costs of the $2^{\text {nd }}$ and $3^{\text {rd }}$ scenarios showed highly positive impact on the milk revenue. Input /output ratios and return /Egyptian pound improved in two proposed scenarios compared to base run scenario by L.E. 0.88 and 0.66 , respectively.

\section{CONCLUSION}

It could be concluded that, incorporation of corn silage and berseem hay in dairy animal's rations led to reduce 0.90 and 0.45 tons of CFM and 6.75 and 6.5 tons of wheat straw for five dairy animals in SII and SIII, respectively. Cultivated Berseem areas could be reduced by 6 and 11 kirats for SII and SIII, respectively compared with base run scenario (SI). Hence, Egyptian wheat areas can be increased with same berseem reduction areas. Summer green forage (corn or sorghum) can be reduced by $25 \%$ to admit increasing rice or any summer crop. Improving feeding quality throughout the balance of energy and protein ratio plus mak- 

system (crops/livestock) as study case

ing use of crops by-products can minimize pollution. Computational model is a powerful tool for integrated scenario development and evaluation for scientists, policy makers, extension workers, teachers and farmers.

\section{REFERENCE}

Abou-Slim, A.A. and Bendary M.M. 2005. Feedstuffs resources in Egypt.Sources and maximization of its utilization.Proc. The $2^{\text {nd }}$ Conf. Anim. Prod. Res. Int., Sakha 27-29 Sept., pp. 57-67.

El-Ashmawy, M.M.I. 2003. Introducing maize silage in winter feeding under dairy animal farm systems in Africa. Ph.D. degree in African Studies-Natural resources (Animal nutrition). The Institute of Africa Research and Studies, Cairo Univ., 27 p.

El-Giziry, A.A., Abd El-hady, M.A.A., Bendary M.M., Sadek, M.F. and Mousa, Kh.M.M., 2010. Utilization of rice straw for feeding ruminants: 3- comparative studies between corn stalks and green rice straw silage during summer feeding. J. Animal and Poultry Mansoura Univ., 1(12), 691-704.

El-Giziry, A.A., Abd El-hady, M.A.A. and Khalil, M.A.I. 2011. Utilization of rice straw silage for feeding ruminants 4 - Economic and nutritional study of corn stalk silage and green rice straw silage in partial replacement of berseem in winter feeding of lactating buffaloes. Egyptian $\mathbf{J}$. Nutrition and Feeds, 14(3), 433-444.

El-Wardani, M.A, El-Ashmawy, M.I., Khalil, M.A., Abdel-Aziz, Y.A. and El-sayes, M.F. 2005. Feed planning system as integrated package to improve mixed farming system. Proc. The $2^{\text {nd }}$ Conf. Anim. Prod. Res. Int., Sakha 27-29 Sept., pp. 447-454.

Ghanem, G.H.A., Bendary, M.M., Gaafar, H.M.A. Draz and Abou-Youssef, M.Z. 2005. Utilization of rice straw for feeding ruminants. 1- Productive performance of lactating cows fed Berseem and different forms of rice straw. Proc.
The $2^{\text {nd }}$ Conf. Anim. Prod. Res. Int., Sakha 2729 Sept., pp. 155-168.

Janssen S. and van Ittersum MK. 2007. Assessing farm innovations and responses to policies: A review of bio-economic farm models. J. of Agric. Systems, 94, 622-636.

Khalil, M.A.I., Shalaby, T.H., El-Wardani, M.A. and Ismail, M.M. 2005. Utilization of farm modeling to increase farm income under small holder dairy mixed farming system. Proc. The $2^{\text {nd }}$ Conf. Anim. Prod. Res. Int., Sakha 27-29 Sept., pp. 439-446.

Khalil, M.A.I., El-Nahas, H.M. and Tag El-Dein, M.M. 2010. Assessment some feeding packages on farm revenue of fattening Friesian calves in the Delta region of Egypt. Mansora Univ. J. of Agric. Sci., 1(9), 425-440.

NRC 2001. Nutrient Requirements of Dairy cattle.National Research Council. $9^{\text {th }}$ Rev. ed. Natl. Acad Sci., Washington, D.C.

Powell J. Mark, Alan Rotz C., Peter A. Vadas and Kristan F. Reed, 2016. Substitutions of corn silage, alfalfa silage and corn grain in cow rations impact $\mathrm{N}$ use and $\mathrm{N}$ loss from dairy farms. Proceedings of the 2016 International Nitrogen Initiative Conference, "Solutions to improve nitrogen use efficiency for the world", 4-8 Dec. 2016, Melbourne, Australia. www.ini2016.com, pp. 4-8.

Schils, RL, de Haan, M.H., Hemmer, J.G., van den Pol, van Dasselaar A., de Boer J.A., Evers, A.G., Holshof, G., van Middelkoop J.C. and Zom, R.L. 2007. Dairy Wise, a wholefarm dairy model. J. Dairy Sci., 90(11), 53345346.

Thornton, P.K. and Herrero, M. 2001. Integrated crop-livestock simulation models for scenario analysis and impact assessment. J. of Agric. Systems, 70, 581-602.

Youssef, M.S.S. 1978. Nutritional status of livestock in Egypt. In symposium on the role of scientific research in sowing feedstuffs, 19-20 Sept., Cairo, Egypt. pp. 63-72. 
Appendix 1. Area unit production of feed stuffs used in animal feeding in El-Beheira according to Economic Affairs sectors 2014

\begin{tabular}{|c|c|c|}
\hline Feed stuff & $\begin{array}{c}\text { Average production/feddan } \\
\text { (Ton) }\end{array}$ & $\begin{array}{c}\text { Average production/kirat } \\
\text { (kg) }\end{array}$ \\
\hline Berseem & 31.68 & 330 \\
Wheat straw & 2.50 & 104 \\
Corn silage & 17.25 & 719 \\
\hline
\end{tabular}

These prices were according the year 2015

There are two transitional periods (two months) between winter and summer did not count in the calculation.

Appendix 2. Feed stuffs prices used in animal feeding in studied areas

\begin{tabular}{|l|c|c|}
\hline \multicolumn{1}{|c|}{ Feed stuff } & $\begin{array}{c}\text { Price/kg } \\
\text { (L.E.) }\end{array}$ & $\begin{array}{c}\text { Feeding period } \\
\text { (day) }\end{array}$ \\
\hline Concentrate feed & 3.50 & 300 \\
Berseem & 0.30 & 150 \\
Wheat straw & 1.00 & 300 \\
Corn silage & 0.30 & 150 \\
\hline
\end{tabular}

